\title{
ІНТЕЛЕКТУАЛЬНІ ОБ'ЄКТИ ІНВЕСТИЦІЙНОЇ ДІЯЛЬНОСТІ: КОМПЛЕМЕНТАРНІСТЬ ТА ВІДМІННІСТЬ
}

\section{INTELLECTUAL OBJECTS OF INVESTMENT ACTIVITY: COMPLIMENTARYNESS AND DISTINCTION}

\author{
Никифоров Анатолій Євгенович \\ доктор економічних наук, доцент, \\ ДВНЗ «Київський національний економічний університет \\ імені Вадима Гетьмана» \\ ORCID: https://orcid.org/0000-0001-8480-0870
}

Nykyforov Anatolii

Kyiv National Economic University named after Vadym Hetman

\begin{abstract}
Стаття присвячена актуальним питанням визначення сутності та ознак інтелектуального потенціалу країни; розкриваються спільні та відмінні риси інтелектуального потенціалу та інтелектуального капіталу; обґрунтовується структура та характеристики складових інтелектуального потенціалу; досліджується система фракторів, що фрормують інтелектуальний потенціал; висвітлюється роль ринку та держави у транссрормації інтелектуальних ресурсів, мобілізації інтелектуального потенціалу та формуванні інтелектуального капіталу. Досліджується ресурсний генезис інтелектуального потенціалу. Інтелектуальні ресурси класифікуються на: людський інтелект, штучний інтелект та інтелектуальні продукти.
\end{abstract}

Ключові слова: інтелектуальні ресурси, інтелектуальний потенціал, інтелектуальний капітал, інвестиції, інновації.

Статья посвящена актуальным вопросам определения сущности и признаков интеллектуального потенциала страны; раскрываются общие и отличительные черты интеллектуального потенциала и интеллектуального капитала; обосновывается структура и характеристики слагаемых интеллектуального потенциала; исследуется система фракторов фрормирующих интеллектуальный потенциал; освещается роль рынка и государства в трансорормации интеллектуальных ресурсов, мобилизации интеллектуального потенциала и формирования интеллектуального капитала. Исследуется ресурсный генезис интеллектуального потенциала. Интеллектуальные ресурсы классифицируются на: челове-ческий интеллект, искусственный интеллект и интеллектуальные продукты.

Ключевые слова: интеллектуальные ресурсы, интеллектуальный потенциал, интеллектуальный капитал, инвестиции, инновации.

The article deals with current issues of determining the essence and features of the country's intellectual potential; common and distinctive features of intellectual potential and intellectual capital are revealed; the structure and characteristics of the intellectual potential are substantiated; the system of factors forming intellectual potential is investigated; the role of the market and the state in transforming intellectual resources, mobilizing intellectual capacity and building intellectual capital is highlighted. The resource genesis of intellectual potential is being investigated. Intellectual resources are classified as: human intelligence, which is divided into creative and entrepreneurial abilities; artificial intelligence which consists of systems (technical tools and software products) capable of creating, processing and transmitting information and information databases providing intelligent activity; intelligent products that help create new knowledge and products that help transform new knowledge into innovation. The latter include objects of intellectual property, know-how, good-will. The process of transforming intellectual resources into intellectual potential and, further, its mobilization in the economy in the form of intellectual capital is carried out with the direct influence of state and market. In the first stage of transformations, the state is intended to provide incentives for innovative work, as an intellectual, creative activity of the individual, which has a high social status, and the market - to give impulses of demand for innovative work. In the second phase of transformation, the state creates incentives for innovative entrepreneurship, and the market - forms the impulses of demand for innovation. The need for active state participation in the second stage is caused by the objective information essence of the innovative product and the ability of uncontrolled diffusion.

Keywords: intellectual resources, intellectual capacity, intellectual capital, investment, innovation. 
Постановка проблеми. Використання категорії «інтелектуальний потенціал» у вітчизняній науковій економічної літературі в останній час зустрічається усе частіше. Очевидно, це не випадково. Проблемна ситуація, що склалася в Україні у зв'язку з визначенням стратегії виходу із тривалої фрінансово-економічної кризи, наводить на думку про те, що необхідна модернізація економіки, розвиток економіки знань, головним чинником якої $€$ інтелектуальний потенціал суспільства.

Формування понятійного апарату дослідження інтелектуального потенціалу має випливати 3 провідної ролі людини в економіці знань, кінцевим результатом якої $\epsilon$ виробництво інноваційної високотехнологічної конкурентоспроможної продукції та відтворення й розвиток інтелекту людини. Отже, послідовність стадій перетворення здібностей людей у кінцевий результат економіки знань може бути виражений у виді структуроутворюючого категоріального ряду інноваційної діяльності: інтелектуальні ресурси $\rightarrow$ інтелектуальний потенціал $\rightarrow$ інтелектуальний капітал $\rightarrow$ інноваційна діяльність $\rightarrow$ інноваційний продукт $\rightarrow$ інтелектуальна власність $\rightarrow$ інноваційна продукція. Найважливішими з точки зору есрективності усього процесу трансорормації є його перші стадії - фрормування та мобілізація інтелектуального потенціалу в національній економіці, яке відбувається у ринковому середовищі та під впливом держави. Саме розкриття ролі ринку та держави у цьому процесі визначено як імператив нашого дослідження, який створює теоретичну основу для розробки необхідного, першочергового інструментарію державного управління інноваційною діяльністю в Україні.

Аналіз останніх досліджень і публікацій. Розвитку теорії інтелектуального потенціалу, дослідженню проблем вимірювання, державного управління відтворенням та мобілізацією інтелектуального потенціалу присвячені широко відомі праці українських учених Ю. Бажала, В. Базилевича, О. Бутніка-Сіверського, А. Гальчинського, В. Геєця, А. Гриценко, Б. Данилишина, М. Дробноход, О. Кендюхова, І. Мойсеєнко, Є. Панченко, Ю. Пахомова, В. Семиноженко, В. Ткаченко, Л. Федулової, А. Чухна та ін. Однак, зважаючи на всеохоплюючий характер сучасних системних перетворень, значний шар науковопрактичних проблем поки що залишається не вирішеним.

Виділення невирішених раніше частин загальної проблеми. Найбільш актуальними для України є дослідження процесів формування й відтворення інтелектуального потенціалу, державного управління розвитком економіки знань, впливу інституціонального середовища на трансформацію інтелектуального потенціалу в інтелектуальний капітал, забезпечення реалізації права інтелектуальної власності, підвищення конкурентоспроможності інтелектуального потенціалу країни на шляху до європейської інтеграції тощо. У теоретичному аспекті актуальною залишається проблема розробки понятійного апарату дослідження інтелектуального потенціалу й, зокрема, розмежування категорій «інтелектуальний ресурс», «інтелектуальний потенціал», «інтелектуальний капітал».

Формулювання цілей статті (постановка завдання). Метою статті $є$ дослідження спільних і відмінних рис між інтелектуальним потенціалом та інтелектуальним капіталом й умов, за яких перший з них здатен перетворитися в інтелектуальний капітал суспільства.

Виклад основного матеріалу дослідження. Поняття потенціалу, як відомо, широко використовується у фрізиці у контексті дослідження динамічних систем. Якщо не удаватися до тонкощів, потенціал системи означає ії здатність (можливість) здійснити певну роботу. Зміст цього поняття полягає у тому, що система характеризується величиною здатності до здійснення роботи (дії), яка може бути виміряна. При цьому величина потенціалу залежить як від параметрів самої системи, так й оточення, з яким взаємодіє система. У процесі здійснення роботи величина потенціалу фрізичної системи змінюється. Наукове трактування поняття «потенціал» стосовно суб'єктів соціально-економічних відносин означає «можливості окремої особи, суспільства, держави в який-небудь області (наприклад, економічний потенціал)» [1, с. 948]. Ці можливості також залежать від параметрів суб'єкта, які обумовлені наявними, або такими, які можна отримати, ресурсами та ступеням їх залучення до певної дії. Поняття «ресурс» ототожнюється із запасом - джерелом засобів, якими володіє (розпоряджається) людина, суспільство, держава. В економіці ресурси й потенціал поняття зв'язані, але не тотожні. Ресурси становлять потенціал за умов певної структури, повноти їх використання (віддачі, продуктивності) та якості, що відповідає технології виробництва визначеної продукції (переробки сировини, надання послуг), а та, у свою чергу, відповідає попиту на ринку, тобто взаємодії із 
зовнішнім оточенням. Така десрініція потенціалу використовується, наприклад, у характеристиці сутності термінів «виробнича потужність» - у мікроекономіці, «крива виробничих можливостей» - у макроекономіці тощо.

Отже, у сучасному науковому трактуванні поняття потенціалу суб'єктів економіки можна виділити наступні ознаки: здатність (можливість) здійснення дії; ресурсний генезис; можливість ідентифрікації, виміряння, кількісної оцінки величини; динамічний характер величини; залежність від параметрів суб'єкта економічних відносин та його взаємодії із зовнішнім оточенням; інтегральний характер, який є результатом впливу різноманітних ресурсів та фракторів.

Категорія «інтелектуальний потенціал» може використовуватися стосовно окремих індивідів, соціальних груп, суспільства у загальнонаціональному або глобальному вимірі. При цьому потенціал вищих рівнів інтеграції (соціальних груп і суспільства) - це не більше ніж похідна від інтелектуального потенціалу індивідів. Зрозуміло, що індивідуальний потенціал завжди формується шляхом акумуляції, засвоєння того, що індивід отримує від суспільства. Проте існувати, проявлятися та відтворюватися поза й крім окремих індивідів інтелектуальний потенціал не може. Це також стосується уречевлених елементів інтелектуального потенціалу таких, наприклад, як штучний інтелект чи інтелектуальні продукти, які по суті $є$ накопиченим запасом знань суспільства. Слід відмітити, що кожний 3 цих елементів має власні параметри потенціалу (продуктивність, економічний ефект від використання і тому подібні), але створюватися, залучатися, використовуватися вони можуть лише завдяки інтелекту людини.

Інтелектуальний потенціал як здібність (можливість) здійснення інноваційної діяльності утворює «кантіанська пара» - відособлені та детерміновані один одним розум і розсудливість (підприємницький глузд). Якщо діяльність першого спрямована на оволодіння знаннями, створення нового знання, перетворення їх в інновації, що, власне, $є$ сутністю інноваційної праці, то саме розсудливість $€$ основою інноваційного підприємництва.

Проводячи експлікацію інтелектуального потенціалу слід відмітити його ресурсний генезис. Передусім це людина, яка є носієм інтелекту - природної розумової діяльності, здатності мислити, сукупності розумових функцій, що перетворюють знання на інноваційні продукти. Ця діяльність на сучасному рівні розвитку знань й інсрормаційних техно- логій не може здійснюватися без залучення штучного інтелекту. Під штучним інтелектом ми розуміємо машинне відтворення деяких інтелектуальних дій людини, пов'язаних зі сприйняттям інформації та деякими фрункціями міркування. Інтелектуальна діяльність людини здійснюється на основі засвоєння та використання інсрормації, накопиченої й втіленої в інтелектуальних продуктах. Ця інформація $є$ результатом інтелектуальної праці у попередніх циклах інноваційної діяльності.

Можливість ідентифрікації потенціалу обумовлена дескриптивним змістом цього поняття-відповіддю на питання «кого або чого визначається потенціал?». Стосовно інтелектуального потенціалу такою відповіддю $є$ система ресурсів, які виступають носіями знань, засобами сприйняття та оброблення інсрормації, втіленням знань в інтелектуальних продуктах. Можливість вимірювання та кількісної оцінки величини інтелектуального потенціалу $€$ ффункцією нормативного змісту цієї категорії, оскільки для кожного з цих видів ресурсів не тільки розроблені методи кількісної оцінки й співставлення, але й зібрана досить багата статистика [8].

Динамічний характер величини інтелектуального потенціалу проявляється у тому, що на відміну від фрізичних систем, його використання призводить не до зменшення, a, навпаки, до збільшення потенціалу. Найближчий приклад - використання людиною своїх здібностей для набуття нових знань веде до розвитку, збагаченню його потенціалу. Інтелектуальний потенціал країни, як й людини, постійно змінюється. Висновки щодо його якісних змін можуть бути зроблені за допомогою співставлення потенціалів у різні моменти часу, або компаративним методом, у якому в якості норми використовується приведена величина потенціалу іншої країни чи середня приведена величина потенціалу групи країн.

Величина інтелектуального потенціалу залежить від взаємодії його складових із зовнішнім оточенням. Чим більше людина отримує інфрормації для здійснення інноваційної діяльності, тим більша продуктивність інноваційної праці, тим більше підстав для прийняття підприємницького рішення, отже більшим є її інтелектуальний потенціал. Значною мірою нові знання та інформацію, яка втілена в інноваціях, людина отримує завдяки дифузії, яка відбувається через комунікаційні канали. Це ще один аргумент на користь включення штучного інтелекту до системи ресурсів інтелектуального потенціалу. 
Мобілізація інтелектуальних ресурсів до інноваційної діяльності обумовлена як мотивами самої людини, так й впливом на нього зовнішнього оточення - ринку і держави. Ринок надає імпульси попиту на інноваційні продукти й визначає затребування інноваційної діяльності, яке відображається у системі стимулів. Остання через мотивацію приводить до дії інтелект людини. Держава визначає певні правила фрункціонування ринку, сприяє формуванню стимулів інноваційної діяльності (наприклад. через встановлення заробітної плати спеціалістів у державних закладах освіти і науки, фрормування у суспільстві соціального статусу людей, які займаються інтелектуальною творчою працею), здійснює окремі фоункції відтворення та стимулювання розвитку інтелектуального потенціалу (освіту, атестацію наукових і науково-педагогічних кадрів та інші). Отже величина інтелектуального потенціалу залежить від впливу зовнішнього оточення.

Поняття інтелектуального потенціалу використовується тоді, коли необхідно поєднання різних видів інтелектуальної діяльності. Природно, що усі прояви інтелектуального потенціалу взаємопов'язані Тому його сутність і призначення полягає у тому, що він виконує фрункцію інтегрування його складових компонентів, коли жоден з них окремо недостатній для характеристики виникнення феномену інноваційної діяльності. Інтегральний характер категорії інтелектуальний потенціал в економічних дослідженнях полягає у тому, що вона відображає можливості фрункціонування й розвитку інноваційної економіки за умов використання різноманітних інтелектуальних ресурсів під впливом ринку і держави. Отже на теоретичному рівні усуваються перешкоди для встановлення органічних взаємозв'язків між соціальною психологією, освітою, наукою, технологією, економікою. А на практичному рівні їх єдність забезпечується адекватними формами організації інноваційної діяльності.

Наукові пошуки у рамках концепції інтелектуального потенціалу не $є$ завершеними. Існування різних підходів до трактування категорії «інтелектуальний потенціал» свідчить про наявність проблем, які потребують розв'язання. У сучасних публікаціях дискусію викликають як визначення змісту інтелектуального потенціалу, так і коректність самого терміну, адже поняття «інтелектуальний ресурс», «інтелектуальний потенціал», «інтелектуальний капітал» часто використовуються як синоніми.
Загальний аналіз наукової літератури дозволяє визначити та виокремити три методологічних підходи, які використовуються при визначенні сутності категорії «інтелектуальний потенціал країни».

Перший, ототожнює інтелектуальний потенціал 3 інтелектуальними ресурсами [2, с. 194]. Цей підхід не можна визнати вірним повною мірою, адже хоча інтелектуальний потенціал й має ресурсний генезис, його мобілізація, а, тим більше, величина обумовлена мотивацією людини. Не помічати цього - теж саме, що розглядати людину як істоту, яка не має власних потреб й інтересів і не керується ними у своїх діях, діяльність якої підпорядковується певним із зовні заданим установкам.

Другий підхід значно розширює зміст категорії «інтелектуальний потенціал», включаючи до нього нематеріальні активи [3, с. 95], або, навіть, матеріальні й фрінансові ресурси. Як відомо, до нематеріальних активів належать й таки, які не інтелектуальними за своєю природою, наприклад, права користування природними ресурсами (землею, водою, надрами і т. п.), дозволи на здійснення деяких видів діяльності. Дещо інша проблема виникає, на наш погляд, стосовно належності до інтелектуального потенціалу матеріальних і фрінансових ресурсів, «які задіяні у двох тісно зв'язаних між собою ключових областях інтелектуального життя суспільства - науці й освіті». Згадані матеріальні й фрінансові ресурси за своїм економічним змістом $\epsilon$ інвестиціями в економіку знань. Емпіричними дослідженнями доведений прямий, але не лінійний зв'язок між приростом інтелектуальних ресурсів та інвестиціями [4]. Отже, не можна порівнювати показники, що характеризують ці поняття, безпосередньо ані 3 будь-яким постійним коефіцієнтом. Таким чином, інвестиції ще не означають потенціалу, оскільки ресурси, в які вони вкладаються, можуть бути більшими чи меншими та використані з більшою чи меншою віддачею.

Третій підхід, розглядаючи інтелектуальний потенціал «як здібність працівників до безперервного створення вартості», ототожнює його $з$ інтелектуальним капіталом. Цей підхід найчастіше зустрічається у працях західноєвропейських учених. Він є відображенням, на нашу думку, усталених у цих та інших розвинутих країнах інституціональних чинників використання інтелектуального потенціалу в економіці. Ми маємо на увазі ті чинники, які надає розвинута демократія 
для реалізації інтелектуального потенціалу. У цих країнах, за рахунок високого попиту на інновації, ринок постійно надсилає імпульси запиту на здійснення інноваційної діяльності. Високотехнологічне конкурентоспроможне виробництво у стані задовольнити цей попит. Державна інноваційна політика за допомогою прямих та опосередкованих методів управління сприяє фрормуванню у сорері бізнесу ефрективних стимулів для здійснення інноваційної діяльності, які викликають високу мотивацію інноваційної праці та інноваційного підприємництва. Національні інноваційні системи, маючи потужні інтелектуальні ресурси, матеріально-технічну базу та фрінансове забезпечення, $€$ фрундаментом економіки, основаної на знаннях. За цих умов «коефріцієнт трансфрормації» інтелектуального потенціалу в інтелектуальний капітал $€$ досить високим і відносно стабільним.

При розмежуванні сутності категорій «інтелектуальний потенціал» та «інтелектуальний капітал» варто звернутися до сучасних теоретико-методологічних підходів, які дають можливість віднести знання, навички, здібності та інші властивості індивіда до виробничих ресурсів та представити їх як відповідну срорму капіталу. Переважна більшість економічних теорій спільні у тому, що основними ознаками інтелектуального капіталу $€$ : по-перше, формування капіталу неможливе без здійснення певних фрінансових, матеріальних витрат, а також витрат часу; по-друге, створений і фрункціонуючий капітал надає змогу отримувати доход від його використання; по-третє, властивості людей, залучені у сфреру виробничих відносин використовуються для створення товарів та послуг [5; 6]. Інтелектуальні ресурси фрункціонують у якості капіталу лише частково, вони не повністю залучені у ссреру виробничих відносин. Отже об'єктивними є якісна та кількісна відмінності між залученими, реалізованими в економіці інтелектуальними ресурсами (капіталом) та можливостями цих ресурсів у створенні інновацій (потенціалом).

У визначених первинних поняттях, що відображають ознаки потенціалу і капіталу, відмінності очевидні. Перша з них характеризує можливість використання інтелектуальних ресурсів у процесі інноваційної діяльності, друга - реальне використання цих ресурсів. Виходячи $з$ цього, сутність інтелектуального потенціалу країни можна визначити як можливість здійснення інноваційного розвитку економіки на основі раціонального використання інтелектуальних ресурсів.
Субстанціональною основою інтелектуального потенціалу $є$ інтелектуальні ресурси, до складу яких включається людський інтелект, штучний інтелект, інтелектуальні продукти (рис. 1).

Кожний з цих ресурсів має багато сорер прояву. 3 точки зору фуункціонування в економіці, що основується на знаннях, інтелектуальний ресурс, наприклад, характеризується креативними здібностями, які проявляються у створенні нових знань та інноваційних продуктів, та підприємницькими здібностями, які проявляються у комерціалізації інноваційних продуктів. Ці характеристики виступають об'єктами вимірювання в економіці. Обидві виділені нами характеристики людського інтелекту $€$ одночасно фрункцією декількох елементів: розумових здібностей, стану здоров'я, освіченості. Характеристики штучного інтелекту обумовлені рівнем розвитку програмного забезпечення, технічних засобів обробки і передачі інформації, інфрормаційних баз. Характеристики інтелектуальних продуктів визначаються спектром та якістю нового знання, практичним значенням створених об'єктів промислової інтелектуальної власності та ноу-хау.

Елементи, що належать до певної складової інтелектуального потенціалу, фрормуються під впливом специфрічної системи фракторів. Таксономія цих фракторів здійснюється за ознаками впливу на складові та елементи інтелектуального потенціалу, фрормами та способами впливу (табл. 1).

За формою впливу на інтелектуальний потенціал фрактори поділяються на прямі та опосередковані. Фактори прямого впливу безпосередньо формують елементи інтелектуального потенціалу. До них, наприклад, належать рівень, структура, якість освіти, які визначають освіченість людини. Опосередковані фрактори здійснюють вплив на елементи інтелектуального потенціалу через інші об'єкти. Наприклад, срінансування освіти - $€$ одним з основних чинників усебічного розвитку цієї ссрери, що у свою чергу позначається на освіченості населення країни.

За способами впливу фрактори, що фрормують інтелектуальний потенціал, можуть бути представлені трьома групами: 1) фрактори накопичення інтелектуальних ресурсів; 2) фрактори використання інтелектуальних ресурсів; 3) фрактори відновлення і розвитку. Перша група об'єднує фрактори, що фрормують субстанціональну структуру інноваційного потенціалу. До другої групи належать фрактори есрективної взаємодії із зовнішнім оточенням, 


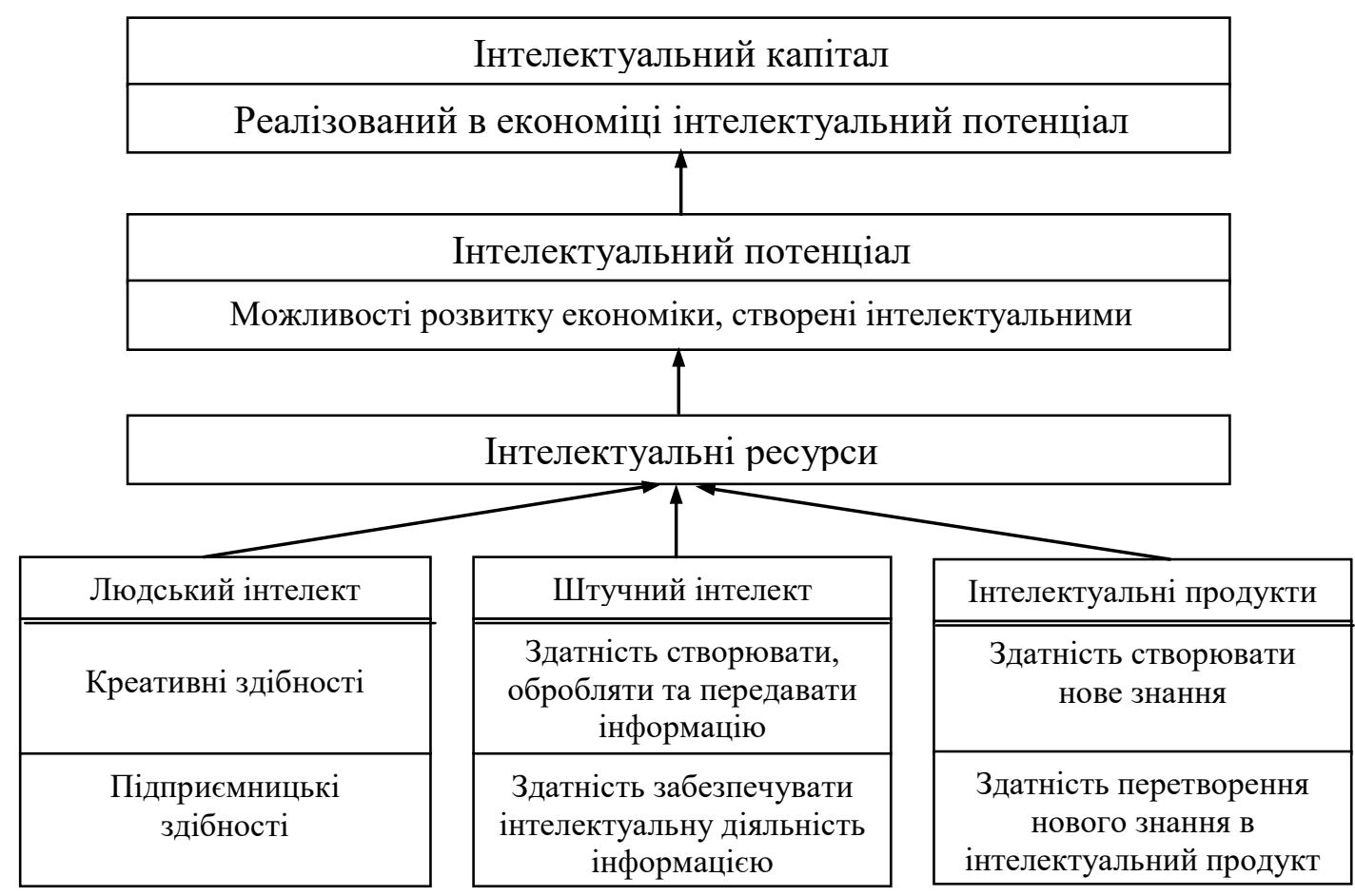

Рис. 1. Структура та характеристики складових інтелектуального потенціалу

Таблиця 1

Фактори, що формують інтелектуальний потенціал

\begin{tabular}{|c|c|c|}
\hline $\begin{array}{c}\text { Складові } \\
\text { інтелектуального } \\
\text { потенціалу }\end{array}$ & $\begin{array}{l}\text { Елементи } \\
\text { інтелектуального } \\
\text { потенціалу }\end{array}$ & $\begin{array}{l}\text { Фактори, що фоормують елементи } \\
\text { інтелектуального потенціалу }\end{array}$ \\
\hline \multirow{3}{*}{ Людський інтелект } & Розумові здібності & $\begin{array}{l}\text { Групи фракторів: генетичні, демограсрічні, } \\
\text { соціокультурні, історичні }\end{array}$ \\
\hline & Стан здоров'я & $\begin{array}{l}\text { Групи фракторів: генетичні, охорони здоров'я, } \\
\text { екологічні, матеріального добробуту }\end{array}$ \\
\hline & Освіченість & $\begin{array}{l}\text { Рівень освіти, структура освіти, якість освіти, } \\
\text { відповідність освіти потребам ринку, орінансування } \\
\text { освіти }\end{array}$ \\
\hline \multirow{3}{*}{ Штучний інтелект } & $\begin{array}{c}\text { Програмне } \\
\text { забезпечення }\end{array}$ & $\begin{array}{l}\text { Комунікативність, комп'ютерна грамотність, якість } \\
\text { освіти, патентування програмного продукту }\end{array}$ \\
\hline & $\begin{array}{l}\text { Технічні засоби } \\
\text { обробки і передачі } \\
\text { інфрормації }\end{array}$ & $\begin{array}{l}\text { Комп'ютеризація населення, розвиток } \\
\text { інфрормаційних мереж, конкуренція на ринку } \\
\text { національних операторів інформаційних мереж }\end{array}$ \\
\hline & Інфрормаційні бази & $\begin{array}{l}\text { Розвиток бібліотечної справи, розвиток патентних } \\
\text { інфрормаційних баз, інтенсивність публікацій, } \\
\text { поширення Інтернету }\end{array}$ \\
\hline \multirow{3}{*}{$\begin{array}{l}\text { Інтелектуальні } \\
\text { продукти }\end{array}$} & Нові знання & $\begin{array}{l}\text { Розвиток освіти, розвиток наукової ссрери, } \\
\text { визнання наукових шкіл, розвиток технологій, } \\
\text { фрінансування науки, суспільний статус наукової } \\
\text { праці }\end{array}$ \\
\hline & $\begin{array}{l}\text { Інтелектуальна } \\
\text { власність }\end{array}$ & $\begin{array}{l}\text { Попит на інновації, конкуренція в інноваційній } \\
\text { сфрері, економічна ефективність, охорона прав на } \\
\text { об'єкти промислової інтелектуальної власності }\end{array}$ \\
\hline & Hoy-xay & $\begin{array}{l}\text { Розвиток технологій, конкуренція на ринку } \\
\text { інновацій, економічна ефективність, охорона } \\
\text { технологічних таємниць }\end{array}$ \\
\hline
\end{tabular}




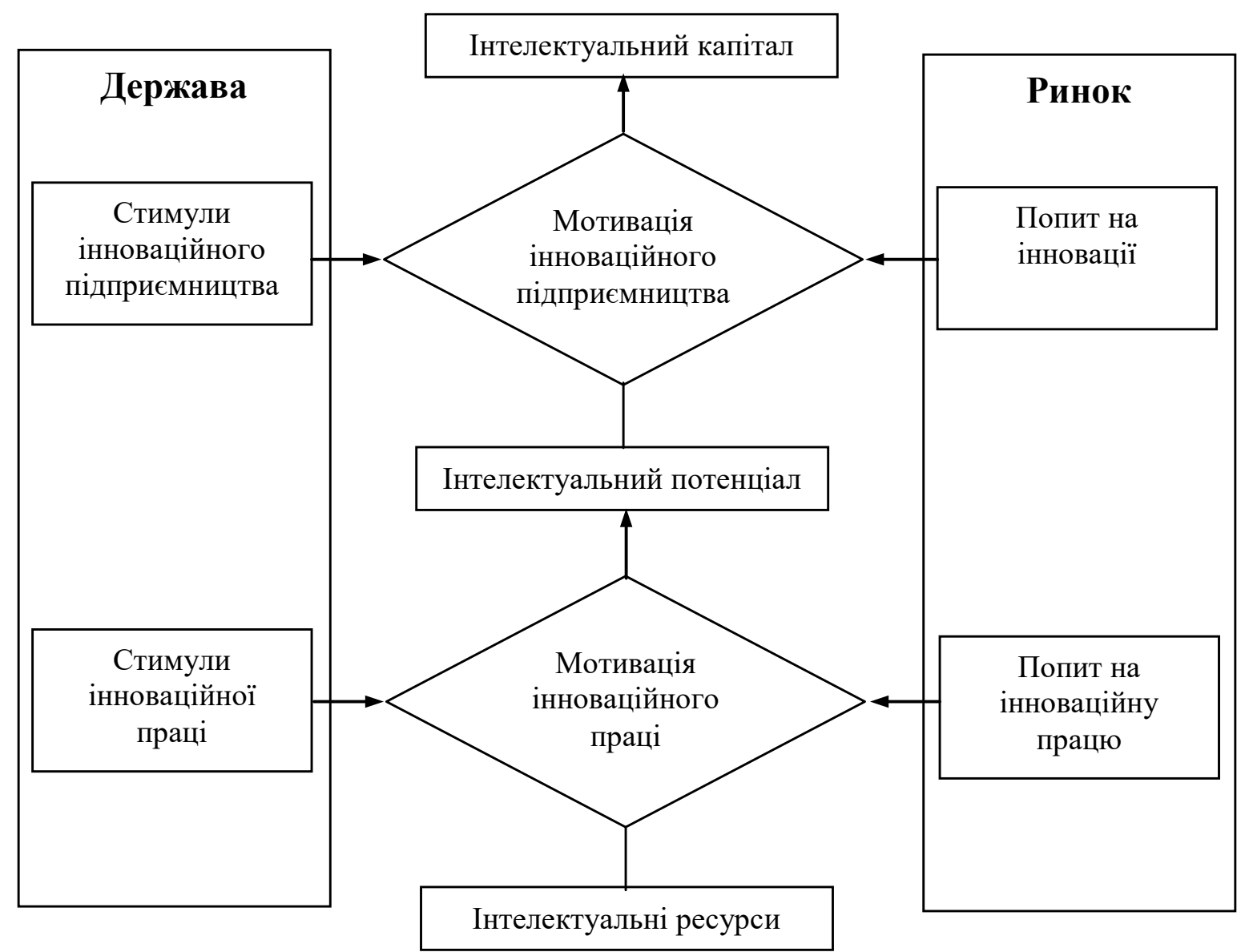

Рис. 2. Трансформація інтелектуальних ресурсів у ринковій економіці

від яких залежить ступінь використання інтелектуальних ресурсів. Зокрема, до цієї групи належать: державне регулювання інноваційної діяльності, попит на інновації, конкуренція на ринку інновацій тощо. У третю групу включаються фрактори, які характеризують процес розширеного відтворення інтелектуального потенціалу (наукова та інноваційна діяльність, у результаті яких збагачується інтелект людини, досягнення науково-технологічного прогресу, які додають нових знань людині, виводячи інтелектуальний потенціал на більш високий рівень.

У наслідок дії фракторів другої групи відбувається процес транссрормації інтелектуальних ресурсів: на першої стадії - фрормування інтелектуального потенціалу, на другої - його мобілізація у ринковій економіці у якості інтелектуального капіталу (рис. 2). Подібного погляду на трансорормування інтелектуального ресурсу дотримується Пітер Друкер, на думку якого «знання саме по собі не $є$ корисним в бізнесі, воно ефективне лише у тій мірі, в якій воно створює користь у житті за межею бізнесу - у світі ринків і споживачів [7, с. 143].
Висновки. 1. «Інтелектуальний потенціал» та «інтелектуальний капітал» - категорії відмінні. Інтелектуальний потенціал країни - це можливість інноваційного розвитку економіки на основі використання інтелектуальних ресурсів. Інтелектуальний капітал країни - це сукупність реалізованого в економіці інтелектуального потенціалу, яка приносить доход та використовується для створенні інноваційного продукту.

2. Інтелектуальний потенціал фрормується під впливом ринку і держави. Попит на інновації стимулює бізнес до інноваційної діяльності. Державна інноваційна політика сприяє фрормуванню у бізнесі стимулів інноваційної праці, які через мотивацію індивідів призводять до мобілізації інтелектуального потенціалу.

3. Інтелектуальний потенціал та інтелектуальний капітал мають різні одиниці виміру. Інтелектуальний потенціал $€$ інтегральним показником можливостей різноманітних ресурсів, кожний 3 яких має специорічні одиниці виміру, для їх компарації можуть використовуватися приведені оцінки за певною шкалою, наприклад, у балах. Інтелектуальний капітал, як функціонуючий актив в економіці, має грошову одиницю виміру. 


\section{СПИСОК ВИКОРИСТАНИХ ДЖЕРЕЛ:}

1. Большой энциклопедический словарь. - 2-е изд., перераб. и доп. / Под ред. А.М. Прохорова. - М.: Большая Российская энциклопедия; СПб.: Норинт, 2004. - 1456 с.

2. Стратегічні виклики XXI століття суспільству та економіці України: В 3 т. / Т. 1: Економіка знань - модернізаційний проект України / За ред. акад. НАН України В.М. Гейця, акад. НАН України В.П. Семиноженка, чл.-кор. НАН України Б.Э. Кваснюка. - К.: Фенікс, 2007. - 544 с.

3. Федулова Л.І. Економіка знаны/ Любов Іванівна Федулова; НАН України; Ін-т екон. та прогнозув. НАН України. - К., 2009. - 600 с.

4. Lin C. Y.-Y., Edvinsson L. National Intellectual Capital: A Comparison of 40 Countries/ Carol Yeh-Yun Lin, Leif Edvinsson. - N.Y.: Springer, 2011. - 384 p.

5. Беккер Г. Человеческое поведение: экономический подход: избранные труди по экономической теории / Г. Беккер. - М.: ГУ ВШЭ, 2003. - 672 с.

6. Schultz T.W. Investment in Human Capital: The Role of Education and of Research / T.W. Schultz. - N.Y.: Free Press, 1971. $-272 \mathrm{p}$.

7. Друкер П.Ф. О профессиональном менеджменте: пер с англ. / Питер Ф. Друкер. - М.: Вильямс, 2006. $320 \mathrm{c}$.

8. Эдвинсон Л. Корпоративная долгота. Навигация в экономике, основанной на знаниях / Лейср Эдвинсон. М.: ИНФРА-М, 2005. - XX. 248 C.

\section{REFERENCES:}

1. The Great Encyclopedic Dictionary (2004). - 2nd ed., re-worker and additional / Under ed. A.M. Prokhorov. Moscow: The Great Russian Encyclopedia; St. Petersburg: Norint, 1456 p. (in Russian)

2. Strategic challenges of the XXI century to society and economy of Ukraine (2007) [Knowledge economics modernization project of Ukraine]. Kiev: Phoenix, 544 p. (in Ukrainian)

3. Fedulova L. (2009) Economics of Knowledge. Kiev: In-t ekon. and predicted. NAS of Ukraine, $600 \mathrm{p}$. (in Ukrainian)

4. Lin C. Y.-Y., Edvinsson L. (2011) National Intellectual Capital: A Comparison of 40 Countries. N.Y.: Springer. $384 \mathrm{p}$.

5. Becker G. (2003) Human Behavior [Economic Approach: Selected Workie on Economic Theory]. Moscow: HSE, 672 p. (in Russian)

6. Schultz T.W. (1971) Investment in Human Capital: The Role of Education and of Research. - N.Y.: Free Press, $272 \mathrm{p}$.

7. Drucker P.F. (2006) About Professional Management. Moscow: Williams, 320 p. (in Russian)

8. Edwinson L. (2005) Corporate longitude. Navigating the knowledge-based economy. Moscow: INFRA-M, 248 p. (in Russian) 